\title{
Rocky reef benthic assemblages in the Magellan Strait and the South Shetland Islands (Antarctica)
}

\author{
Ensambles bentónicos de arrecifes rocosos en el Estrecho de Magallanes \\ e Islas Shetland del Sur (Antártica)
}

\section{Emma M. Newcombe ${ }^{1}$ and César A. Cárdenas ${ }^{1,2}$}

${ }^{1}$ Fundación Centro de Estudios del Cuaternario, Fuego-Patagonia y Antártica (CEQUA), Avenida Bulnes 01890, Punta Arenas, Chile. emmanewcombe@gmail.com

${ }^{2}$ School of Biological Sciences, Victoria University of Wellington, P.O. Box 600, Wellington, New Zealand. cesar.cardenas@vuw.ac.nz

Resumen. - Las comunidades submareales de arrecifes de gran parte de las costas del mundo han sido descritas en detalle, sin embargo, escasa información existe para los extensos arrecifes subantárticos. El objetivo fue describir estos sistemas costeros del sur y medir el grado en que varían en función de las medidas fundamentales de la estructura de la comunidad. La Región Magallánica constituye un sitio intermedio entre sitios relativamente bien estudiados en regiones temperadas y Antártica. Estudios previos sugieren que la especie de alga dominante (dosel) puede reflejar diferentes historias de perturbación así como diferencias en sus comunidades asociadas. Hipotetisamos que la variación en los ensambles submareales sésiles en Magallanes, donde Macrocystis pyrifera domina ampliamente, será menor a la que ocurre en sitios en Antártica, donde Desmarestia spp. o Himantothallus grandifolius dominan dependiendo de los regímenes de disturbios. Los resultados de este estudio muestran que los ensambles bentónicos en el Estrecho de Magallanes fueron similares en aquellos lugares donde la estructura física del arrecife fue similar, pero variaron fuertemente donde la forma del arrecife fue distinta. En los sitios de las Islas Shetland del Sur, los ensambles bentónicos fueron diferentes en términos del alga dominante y la estructura comunitaria. No obstante, la evidencia previa acerca de que sitios dominados por Desmarestia presentan mayor evidencia de disturbios fue incorrecta. Probablemente el efecto de sombra producido por Macrocystis en Magallanes y el efecto del hielo en Antártica son fuertes factores estructuradores en sus respectivas comunidades, situación que debe ser considerada al comparar las características comunitarias.

Palabras clave: Macroalgas, dosel, sustratos duros, Región Magallánica, Océano Austral

\begin{abstract}
Subtidal reef communities from much of the world's coastline have been described in detail, but data from the world's most extensive subantarctic rocky reefs is scarce. The objective was to describe these southern coastal systems and measure the extent to which they vary in terms of fundamental measures of community structure. The Magellan Region constitutes an intermediate site between relatively well-studied temperate regions and Antarctica. Previous studies suggest that dominant canopy species may reflect different disturbance histories and associated communities may similarly be expected to vary structurally. We hypothesized that variation in subtidal sessile assemblages in the Magellan Strait, where Macrocystis pyrifera widely dominates, would be less than at Antarctic sites, where Desmarestia spp. or Himantothallus grandifolius may dominate depending on disturbance regimes. Our results showed that benthic assemblages in the Magellan Strait were similar where physical structure of the reef was similar, but differed strongly where reef form differed. At sites in South Shetland Islands, benthic assemblages differed in terms of dominant macroalgae and sessile community structure; however evidence that the Desmarestia -dominated site was more highly disturbed was equivocal. Shading produced by Macrocystis in Magellan Strait and ice effect in Antarctica are likely strong structuring factors in their respective communities, which would need to be considered when comparing community characteristics.
\end{abstract}

Key words: Macroalgae, canopy, hard substrates, Magellan Region, Southern Ocean 


\section{INTRODUCTION}

Shallow-water rocky reefs are important and productive marine environments, and a large number and diversity of plants and animals are associated with them (Dayton 1985a, Schiel 1990, Steneck et al. 2002). It is important to understand the structure and functioning of natural communities so that current variation and future changes can be understood and managed if necessary. It is, however, impossible to address higher level questions if species assemblages have not been described (Schiel \& Hickford 2001).

Mainland South America (which extends to nearly $54^{\circ} \mathrm{S}$ ) and the Fueguian Archipelago (to nearly $56^{\circ} \mathrm{S}$ ) constitute a substantial part of the world's subantarctic coastline, but these may be the least-studied near-shore rocky reef communities in the world (Escribano et al. 2003). The vast majority of the subtidal studies developed in the Magellan Region has been carried out in soft bottom habitats, and although rocky reefs are common coastal habitats in the Magellan Region, very little is known about communities inhabiting those (Försterra et al. 2005). In recent years there have been a number of subtidal rocky reef studies developed in steep fjord environments in the north of the Magellan Region (e.g., Häussermann \& Försterra 2007). In the south some work has been developed in the intertidal cobble-boulder fields in sites along the Magellan Strait (e.g., Benedetti-Cecchi \& Cinelli 1997, Ríos \& Mutschke 1999, Ingólfsson 2005) and Cape Horn Archipelago (e.g., Guzmán \& Ríos 1986), and invertebrate communities of the kelp Macrocystis pyrifera (Linnaeus) C. Agardh, 1820 were studied in the Magellan Strait (Ríos et al. 2007) and the Beagle Channel (Ojeda \& Santelices 1984, Adami \& Gordillo 1999). Ecological studies are equally scarce (but see Castilla \& Moreno 1982, Dayton 1985b, Vásquez \& Castilla 1984, Vásquez et al. 1984).

Comparative quantitative data from subtidal benthic assemblages have not been published (but see Ríos et al. 2007 for work on fauna from Macrocystis pyrifera holdfasts), and while substantial between-site variation has been shown in the intertidal (Benedetti-Cecchi \& Cinelli 1997), M. pyrifera dominance along most of the Magellan Strait may suggest a more homogeneous subtidal community, as the kelp forests may provide structuring features for the communities (Ríos et al. 2007).

The Magellan Region constitutes an intermediate site between temperate regions and Antarctica, but there is a scarcity of comparative studies between them (Arntz 2005). The South Shetland Islands off the Antarctic
Peninsula are less remote from the Magellan Strait than well-studied sites widely termed «southern Chile» in the ecological literature. Biogeographic affinities have been found between the Antarctic Peninsula and the Magellan Region for different groups of invertebrates (Moyano 1996, Thatje \& Brown 2009). It is, however, still unclear to what extent the benthic communities inhabiting both regions are related (Thatje \& Mutschke 1999) and more studies are needed in order to have a better understanding of differences and similarities existing between these areas. Perhaps surprisingly, the Magellan Region is the less well-studied region of the two (Arntz 2005).

At Subantarctic Islands and Antarctic Peninsula sites, seaweeds and sessile fauna are largely absent from the intertidal (Castilla \& Rozbaczylo 1985, Kim 2001). Subtidally, faunal dominance is common below the iceaffected shallow sublittoral, community structure tends to be dominated by bryozoans, ascidians and sponges (Barnes 1995, Bowden 2005, Smale 2008). Coralline algae and summer growth of annual red macroalgae may be abundant, perennial brown algae are almost always absent in the shallows, but may be abundant below $\sim 5-10$ m (Gruzov \& Pushkin 1970, Sakurai et al. 1996, Quartino \& Boraso de Zaixso 2008). Dominant canopy species may reflect different disturbance histories (Dayton 1990) and associated communities may similarly be expected to vary structurally (Clark et al. 2011).

For development of comparative studies it is important to have information collected with the same methodology. Moreover, Antarctic sites easily accessible from Chilean bases are likely to be more readily accessible to researchers working in the Magellan Region, and present an opportunity for extending ecological research across a large latitudinal gradient. Here, we take steps to fill the knowledge gap in Magellanic rocky reef macroalgal community ecology by describing the composition and structure of benthic assemblages and measuring variation between locations. We hypothesized that variation in subtidal sessile assemblages along the eastern mainland coast of the Magellan Strait (where Macrocystis pyrifera widely dominates (Dayton 1985b, Ríos et al. 2007)) would be less than at Antarctic sites (where Desmarestia spp. or Himantothallus grandifolius may dominate (Dayton 1990, Klöser et al. 1996)). We aimed to measure the extent to which these southern coastal systems are similar in terms of fundamental measures of community structure (algal dominance, diversity, composition, abundance). 


\section{Materials AND MEthods}

\section{STUDY AREA}

Shallow-water rocky reefs benthic assemblages of the Magellan Region and Antarctica were studied during the austral summer, from December 2008 to February 2009. Sites were selected according to their accessibility and the existence of nearby facilities for sample processing and facilitation of planning and coordination of research efforts (Iken \& Konar 2003). Four sites were studied in the Magellan Strait: Puerto del Hambre (5336'57"S; 7055’43"W), Fuerte Bulnes (533’3'"S; 7055’13"W), Punta Carrera (533' $10^{\circ} \mathrm{S}$; 7055’32"W) and Punta Arbol (53॰43’07 S; 7057’58"W) (Fig. 1).

In Antarctica, two sites were chosen within Maxwell Bay, King George Island, South Shetland Islands. Maxwell Bay is one of two large fjords of the island, facing southeast to Bransfield Strait (Kim 2001). Nebles Point is located at the entrance of Collins Bay (62¹1'02"S; 5851'14"W) close to Collins Glacier. The Fildes Bay site (62¹2’17"S; $\left.58^{\circ} 56^{\prime} 47^{\prime \prime W}\right)$ was on the Maxwell Bay side of Albatross Islet (Fig. 1).

\section{SAMPLE COLLECTION}

Rocky reef communities were sampled based on the protocols of NaGISA (Rigby et al. 2007). Depth-stratified random sampling was carried out in series of $1 \mathrm{~m}^{2}$ quadrats. At the Magellanic sites, five quadrats were sampled at each depth. Intertidal strata were sampled at high (HT), medium (MT) and low tide (LT) levels. Subtidal sampling was done on SCUBA at 1, 3, 5, 10 and 20 m depth levels, where accessible. The $20 \mathrm{~m}$ depth level was sampled only at Fuerte Bulnes where it was accessible due to the steepness of the reef to $30 \mathrm{~m}$. The Puerto del Hambre site was sampled to $10 \mathrm{~m}$. At Punta Carrera and Punta Arbol sandflats began at less than $5 \mathrm{~m}$ and $3 \mathrm{~m}$ respectively. When placing quadrats, large holdfasts ( $>10 \mathrm{~cm}$ diameter) of Macrocystis pyrifera were avoided, as these were studied by Ríos et al. (2007), and the associated cryptic organisms would be poorly represented with the methods we employed. At the Antarctic sites, poor weather severely restricted sampling time and scope. Four quadrats were placed at each of 1,5 and $10 \mathrm{~m}$ depths at both sites, and at one level in the intertidal at Fildes Bay.

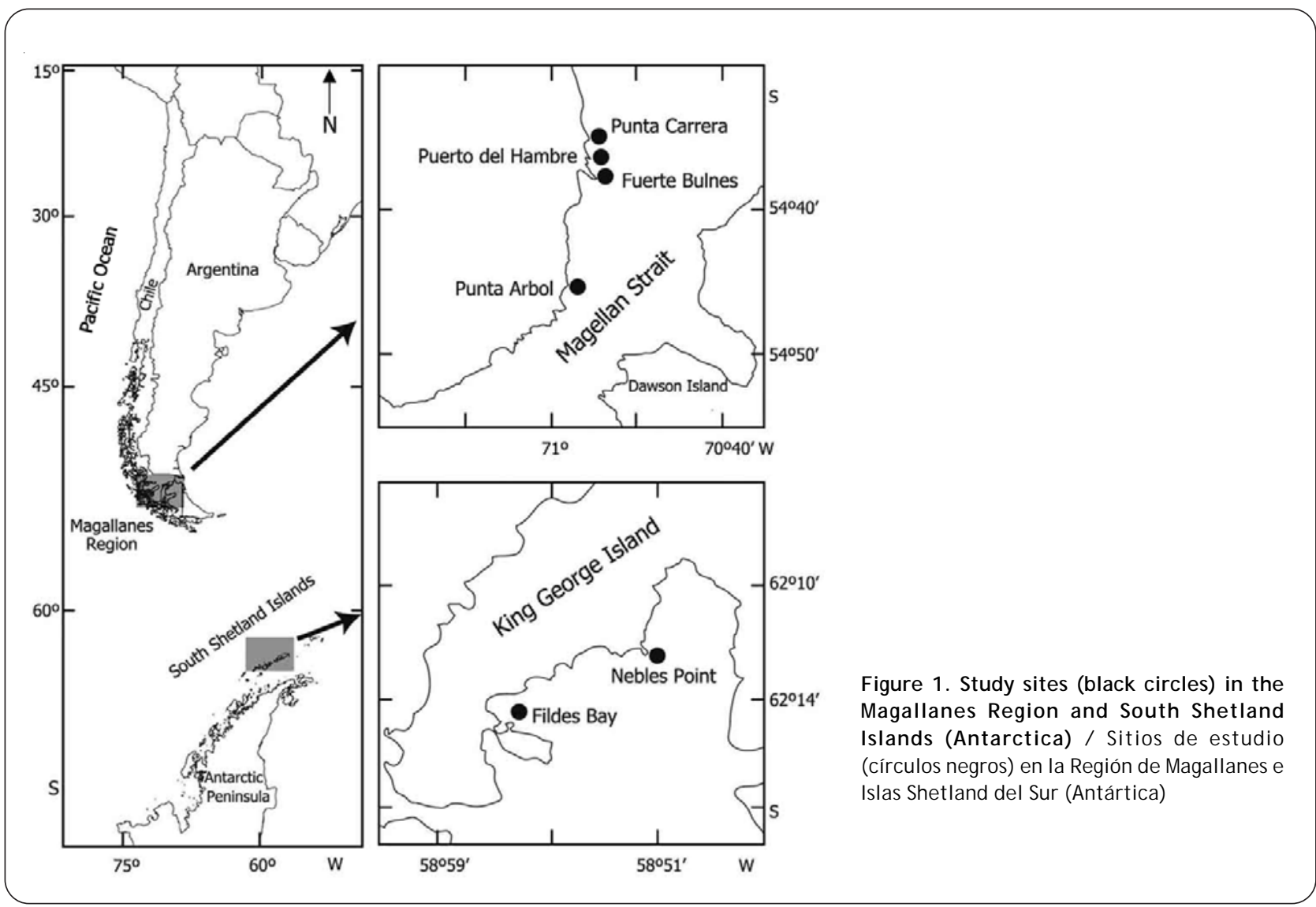


Each $1 \mathrm{~m}^{2}$ quadrat was divided in quarters with elastic cord and marked with coloured plastic at $10 \mathrm{~cm}$ intervals to assist in assigning close ups to the correct area of the quadrat. Each quarter was photographed from directly above. A series of close ups recorded any reef face obscured by macroalgae or reef form. Additionally, the presence or absence of surface canopy of Macrocystis pyrifera was noted in the Magellan Strait sites. Photographs were later analysed for data collection. The dominant substrate type was ranked on a scale of fineness as: Bedrock $=4$; Boulders $=3$; Cobbles $=2$; Gravel $=1$, Sand $=0$. All organisms larger than $2 \mathrm{~cm}^{2}$ were identified to the lowest possible taxonomic level and percent cover of sessile invertebrates and macroalgae was estimated. Macroalgal cover (excluding surface canopy of Macrocystis pyrifera fronds) and cover of all sessile organisms on the reef face were recorded (percent cover) and mobile fauna were counted. Macroalgae were collected for identification where necessary, and were mostly identified to genus. Specimens were fixed with $10 \%$ formaldehyde in seawater (buffered) or in $70 \%$ alcohol. The taxonomic status of each species was confirmed according to WoRMS database ${ }^{1}$.

The community structure and composition at each site were analysed for species richness (S) and ShannonWiener diversity $\left(\mathrm{H}^{\prime}\right)$. Differences in number of species and diversity between sites were tested using one-way ANOVA. Shapiro-Wilk's normality test and Levene's test for homogeneity of variances were performed before the analysis.

Percent coverage data were log-transformed in order to downweigh the influence of extreme values (i.e., rare species) to test differences in percent coverage between depths, sites and areas. A similarity matrix was developed based on Bray-Curtis similarity index. Multivariate patterns between regions and sites were visualized in nMDS (non-Metric Multidimensional Scaling) plots. Ordinations with centroids averaged by site were produced to depict variability between regions and sites.

Analyses of Similarity (ANOSIM) were performed to test differences between the different factors where area, site and depth were considered $a$ priori factors for the analysis. When the global $R$-value was significant $(P<$ 0.05), pairwise comparisons were conducted. Thus, interpretations of pairwise comparisons were based on $R$-values rather than $P$ values as recommended by Clarke \& Gorley (2006). SIMPER analysis was then performed to assess the contribution of each taxon to observed dissimilarities between groups. The same routine was undertaken for comparisons with mobile data where number of individuals was square root transformed. ANOSIM and SIMPER procedures were run using PRIMER v6 (Clarke \& Gorley 2006).

\section{RESULTS}

Substrate was largely rocky at two sites in the Magellan Strait (Fuerte Bulnes and Puerto del Hambre) while Punta Arbol and Punta Carrera became sandy at 3 and $5 \mathrm{~m}$, respectively. Sites in Antarctica were also mostly rocky, although bedrock was more common at Nebles Point, and boulders more common at Fildes Bay (Fig. 2).

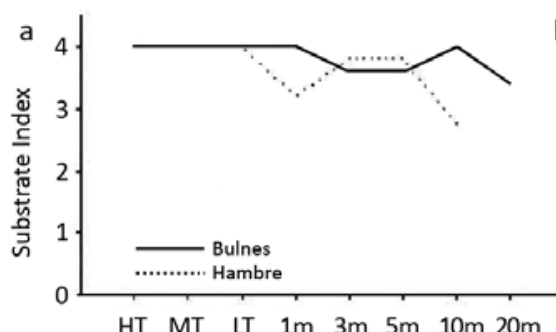

HT MT LT $1 \mathrm{~m} \quad 3 \mathrm{~m} \quad 5 \mathrm{~m} \quad 10 \mathrm{~m} \quad 20 \mathrm{~m}$

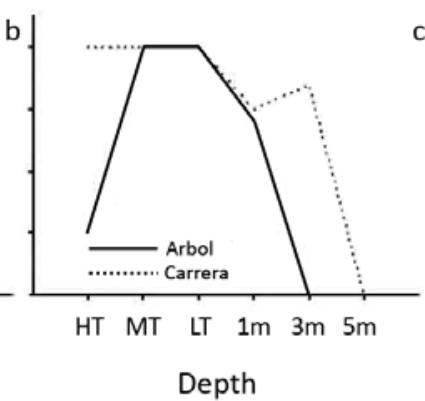

Depth

Figure 2. Substrate type with increasing depth in the Magellan Strait (a, b) and South Shetland Islands, Antarctica (c). Indices generated by assigning a number to the dominant substrate in each quadrat (Bedrock $=4$, Boulders $=3$, Cobbles $=2$, Gravel $=1$, Sand $=0$ ) and averaging across all quadrats from each depth / Tipo de sustrato de acuerdo a la profundidad en el Estrecho de Magallanes (a, b) e Islas Shetland del Sur, Antártica (c). Índices generados asignando un número según el sustrato dominante en cada cuadrante (Roca $=4$, Bolones $=3$, Cantos rodados $=2$, Grava $=1$, Arena $=0$ ) y valores promedios de todos los cuadrantes en cada profundidad

${ }^{1}$ World Register of Marine Species «ttp:// www. marinespecies. org> 
A total of 168 taxa (106 in Magallanes, 62 in Antarctica) were recorded from 141 quadrats studied across all sites. Overall species richness was higher in Magellan Strait sites than in Antarctic sites. The highest number of species was recorded in Fuerte Bulnes (83 taxa) whereas Fildes Bay showed the highest value (27 taxa) in Antarctica.

In the Magellan Strait, the sessile fauna in the intertidal was dominated by bivalves ( 3 taxa) and ciripedians (3 taxa), while the subtidal fauna was dominated by the Ascidiacea (9 taxa), Porifera (6) and Bryozoa (6) ${ }^{2}$. In Antarctica, the sessile fauna was dominated by Porifera (18 taxa) and Ascidiacea (7 taxa). The mobile intertidal fauna in the Magellan Strait was dominated by molluscs (5 taxa) and echinoderms (2 taxa). In the subtidal, the mobile fauna was dominated mainly by molluscs (19 taxa) and echinoderms (12 taxa), especially echinoids and asteroids. At Antarctic sites, the limpet Nacella concinna (Strebel, 1908) was the only species found in the intertidal. Subtidal assemblages were dominated by echinoderms (9 taxa) and molluscs (4 taxa).

The mean number of taxa per quadrat (including sessile and mobile organisms) in the intertidal varied significantly across sites $\left(F_{4,76}=8.812, P<0.001\right)$. The highest value was recorded at Fuerte Bulnes (5.1 $\pm 0.5 \mathrm{SE})$ and lowest in Fildes Bay (Fig. 3a). Subtidally, values were also significantly different between sites $\left(F_{5,82}=3.367, P<\right.$ 0.001). Species richness per quadrat at the Magellan Strait sites ranged from $10.6( \pm 1.5)$ at Punta Arbol to $6.2( \pm 0.5)$ at Punta Carrera, while in Antarctica, Fildes Bay showed the highest number of species per quadrat $(6.8 \pm 0.59$; Fig. 3a). Diversity varied across sites at the intertidal $\left(F_{4,76}\right.$ $=2.976, P<0.01)$ and subtidal levels $\left(F_{5,82}=3.686, P<\right.$ $0.05)$. In the intertidal, the highest diversity was found at Fuerte Bulnes whereas subtidally the highest diversity at subtidal depths was recorded at Punta Arbol in the Magellan Strait, and Nebles Point in Antarctica. Interestingly, Fuerte Bulnes showed the highest diversity at the intertidal levels $(0.8 \pm 0.2)$ and the lowest $(0.4 \pm 0.1)$ in the subtidal (Fig. 3b).

Subtidal macroalgal cover (not including the surface canopy formed by Macrocystis pyrifera fronds) ranged from $<5 \%$ (Fuerte Bulnes $20 \mathrm{~m}$ ) to $>80 \%$ (Fuerte Bulnes and Puerto del Hambre 1 m, Nebles Point, 5 and 10 m, Fig. $4 \mathrm{a}-\mathrm{c})$. These dense canopies were dominated by Lessonia vadosa (Searles, 1978) in the Magellan Strait and Desmarestia spp., at Nebles Point, South Shetland Islands. Macrocystis pyrifera also formed a dense surface canopy at some depths at all sites in the Magellan Strait.

In general, macroalgal cover (non-surface canopy) tended to decrease with increasing depth at the Magellan Strait sites, except at Puerto del Hambre, where there was an increase in coverage at $10 \mathrm{~m}$ due to high abundance of Lessonia flavicans (Bory de Saint-Vincent, 1826). High cover ( $>50 \%$ ) did not occur below a surface canopy of Macrocystis (Fig. 4a, b). At the Antarctic sites, the canopy cover increased with depth, reaching high values where the brown algae Himantothallus grandifolius (Gepp \& Gepp) Zinova, 1959 and Desmarestia spp. dominated at Fildes Bay and Nebles Point respectively. The red algae
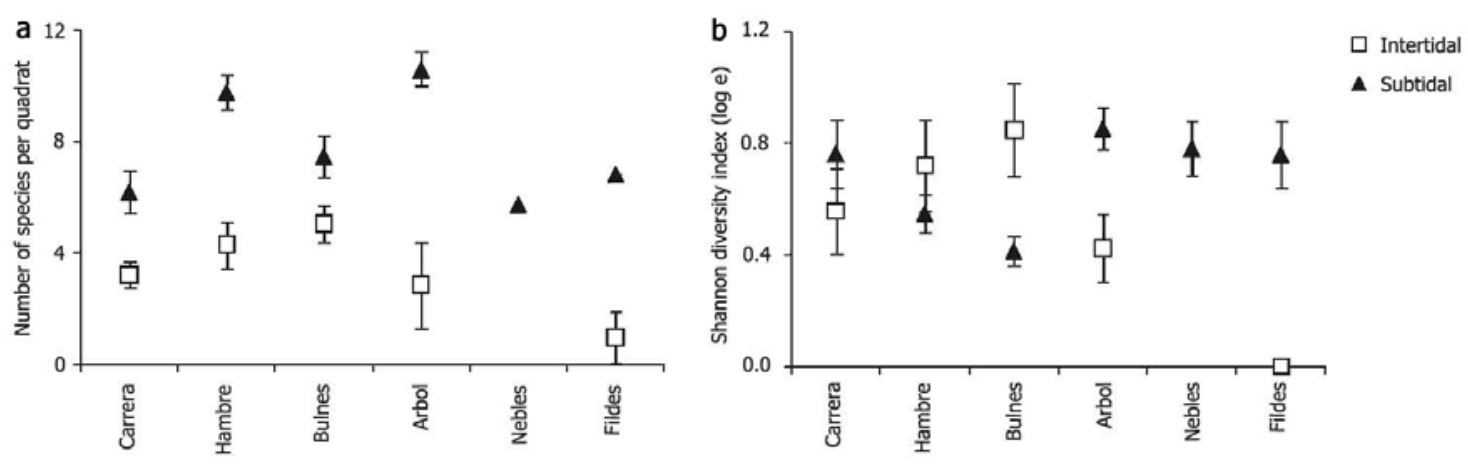

Figure 3. a) Species richness and b) diversity at four sites in the Magellan Strait and two sites in the South Shetland Islands, Antarctica. Error bars indicate 1 SE / a) Riqueza de especies y b) diversidad en cuatro sitios en el Estrecho de Magallanes y dos sitios en las Islas Shetland del Sur, Antártica. Barras de error indican $1 \mathrm{EE}$

${ }^{2}$ Appendix 1. List of species available by email from authors. 


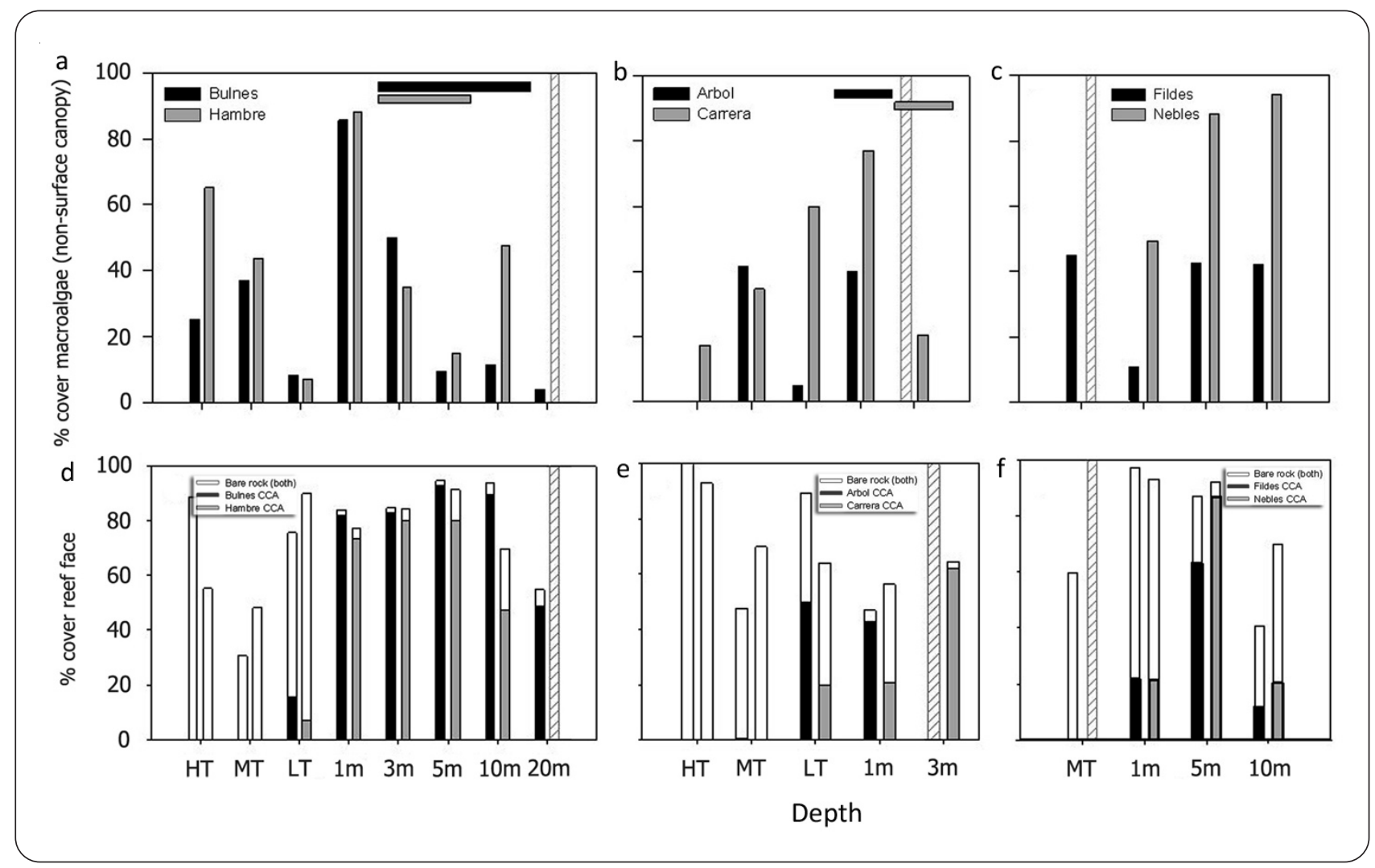

Figure 4. Mean percent cover of fleshy seaweeds (a-c), crustose coralline algae (CCA) and bare rock (d-f) with increasing depth at sites in the Magellan Strait (a, b, d, e) and South Shetland Islands, Antarctica (c, f). Surface canopy of Macrocystis pyrifera is indicated by horizontal bars at top of graphs a and $\mathbf{b}$. Grey striped bands indicate data not collected / Promedio de porcentaje de cobertura de algas laminares (a-c), algas coralinas crustosas (CCA) y roca (d-f) en relación al aumento de profundidad en el Estrecho de Magallanes (a, b, d, e) e Islas Shetland del Sur, Antártica (c, f). El dosel de Macrocystis pyrifera se indica con las barras ubicadas en la parte superior de los gráficos a y b. La barra gris con bandas indica datos no colectados

Porphyra sp. was the most important species at intertidal levels in Magallanes. Other important species include Mazzaella laminarioides, which was dominant at midtide in Punta Carrera and Punta Arbol, but dominant at low-tide only at Punta Carrera.

There were large areas of available space (bare rock) in the intertidal, but generally very little $(0-36 \%)$ in the subtidal in Magellan Strait sites. Encrusting coralline algae were the most important organisms in all sites in the Magellan Strait (Fig. 4d, e). They were highly dominant along the subtidal, especially at Fuerte Bulnes and Puerto del Hambre, covering more than $60 \%$ of the substrate. In contrast, the cover of both bare rock and encrusting corallines was similar at the Antarctic sites (Fig. 4f). The area of bare rock was higher than coverage of corallines in Fildes Bay, reaching values of $75 \%$ at $1 \mathrm{~m}$ while corallines only covered $21 \%$ at that depth. The coverage of coralline algae at Nebles Point was slightly higher than bare rock with values near $49 \%$ at $10 \mathrm{~m}$. At Magellan Strait sites, the most important organisms after macroalgae were bivalves, cirripedians and ascidians, whereas bryozoans and sponges were important in Antarctic sites.

Fildes Bay had the highest densities of mobile individuals of all sites, reaching an average of over 50 individuals $\mathrm{m}^{-2}$ at $5 \mathrm{~m}$ depth. The overwhelming majority of these (81\%) were the limpet Nacella concinna. Densities of mobile animals ranged between $2.6( \pm 0.9)$ individuals $\mathrm{m}^{-2}$ at Punta Carrera $(1 \mathrm{~m})$ and $61.5( \pm 11.8)$ individuals $\mathrm{m}^{-2}$ at Fildes Bay (5 m; Fig. 5). In the Magellan Strait there was generally a more even contribution of molluscs and echinoderms than at the Antarctic sites, except at Punta Arbol where high densities of the small urchin Pseudechinus magellanicus (Philippi, 1857) at 1 $\mathrm{m}$ depth contributed an average of $80 \%$ of the total of 44.2 ( \pm 21.6$)$ individuals $\mathrm{m}^{-2}$. 


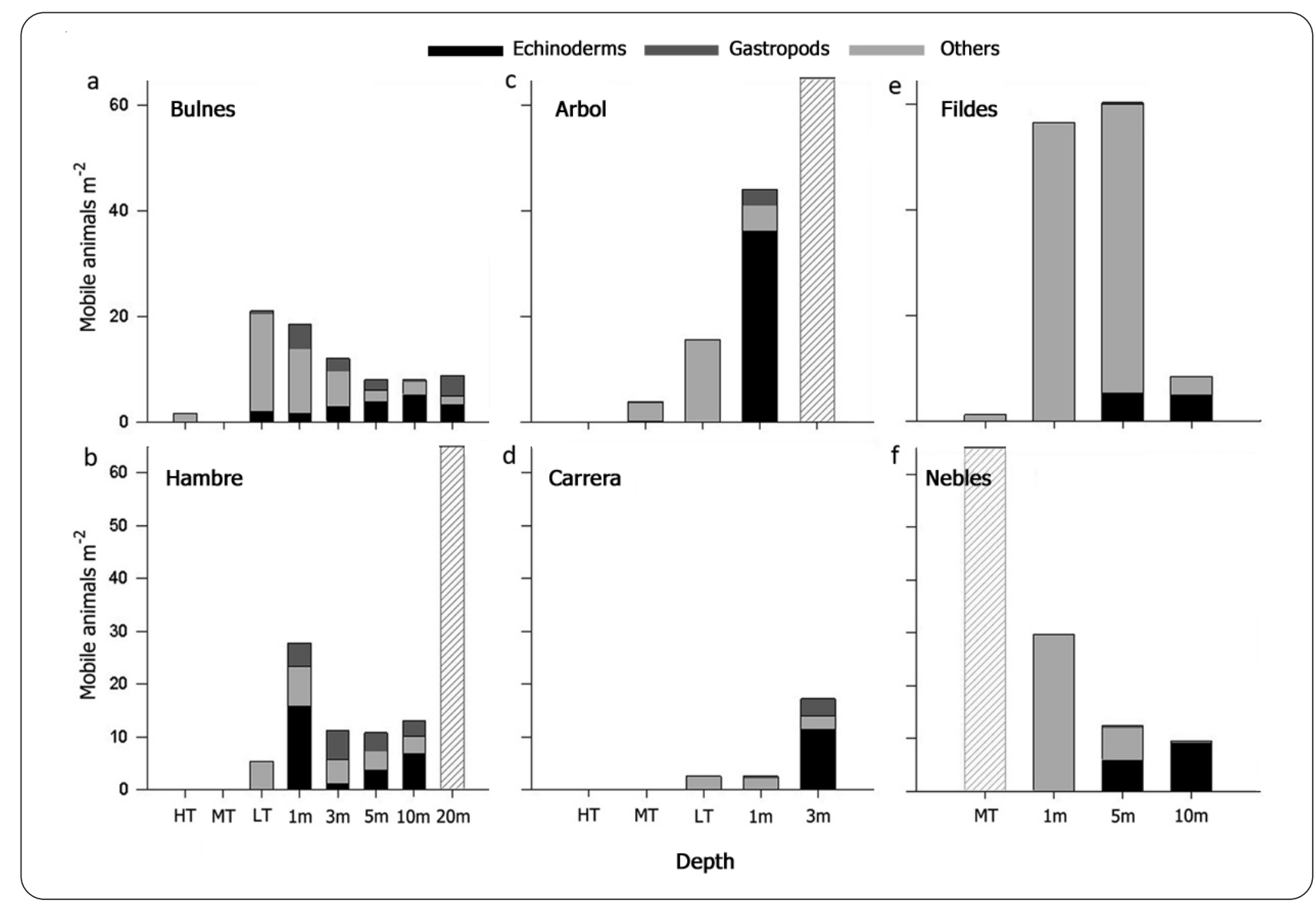

Figure 5. Number of mobile individuals (Gastropoda and Echinodermata) with increasing depth at sites in the Magellan Strait (a-d) and the South Shetland Islands, Antarctica (e, f). Grey striped bands indicate data not collected / Número de individuos móviles (Gastropoda y Echinodermata) en relación al aumento de la profundidad en sitios del Estrecho de Magallanes (a-d) e Islas Shetland del Sur, Antártica (e, f). La barra gris con bandas indica datos no colectados

Clear differences in community structure of sessile assemblages (across all intertidal or subtidal depths) between regions were identified by the nMDS (ANOSIM Global $R$ : $0.85 P=0.05$; Fig. 6). Differences between sites were highest in Antarctica, while Magellan Strait sites were grouped into pairs for subtidal assemblage data. The composition of sessile assemblages differed significantly between sites across studied levels/depths (ANOSIM Global $R$ : $\mathrm{HT}=0.52, \mathrm{MT}=0.35, \mathrm{LT}=0.56,1 \mathrm{~m}$ $=0.48,3 \mathrm{~m}=0.45, P=0.001 ; 5 \mathrm{~m}=0.43,10 \mathrm{~m}=0.55, P=$ 0.01 ). Pairwise tests showed high dissimilarities between Punta Carrera and Punta Arbol when compared to other sites in the Magellan Strait (Table 1), whereas Fuerte Bulnes and Puerto del Hambre showed significant differences in the subtidal from 3 to $10 \mathrm{~m}$ but not in the intertidal.
Several sessile taxa were responsible for dissimilarities between sites and levels/depths ${ }^{3}$. In Magallanes, the red algae Porphyra sp. was the most important species in terms of cover at high-tide while the cirripedian Notochtamalus scabrosus (Darwin, 1854), the bivalve Perumytilus purpuratus (Lamarck, 1819), and the macroalgae Mazzaella laminarioides were the most discriminant species at mid- and low-tide between sites. Percent cover of the kelp Lessonia vadosa was the main differentiator between sites at $1 \mathrm{~m}$, as observed differences are explained by the absence of this species at Punta Arbol and Punta Carrera. Dissimilarities between Fuerte Bulnes and Puerto del Hambre at $10 \mathrm{~m}$ were mainly caused by differences in coverage of encrusting corallines and Macrocystis pyrifer ${ }^{3}$. This species was more abundant at this depth at Fuerte Bulnes, while Gigartina

${ }^{3}$ Appendix 2. Detailed analyses available by email from authors. 
Table 1. $R$ values of pairwise tests for comparisons between sessile assemblages at different sites studied in the Magellan Strait. (* = significant differences). High (HT), medium (MT) and low tide (LT) levels / Valores $R$ de las pruebas de comparación pareadas entre ensambles sésiles de diferentes sitios estudiados en el Estrecho de Magallanes ( $*$ diferencias significativas). Niveles de alta (HT), media (MT) y baja marea (LT)

\begin{tabular}{|c|c|c|c|c|c|c|}
\hline \multirow[b]{2}{*}{ Fuerte Bulnes } & \multicolumn{2}{|c|}{ Puerto del Hambre } & \multicolumn{2}{|c|}{ Punta Arbol } & \multicolumn{2}{|c|}{ Punta Carrera } \\
\hline & HT & 0.05 & HT & $0.54^{*}$ & HT & $0.61^{*}$ \\
\hline & MT & 0.02 & MT & 0.06 & MT & $0.64^{*}$ \\
\hline & LT & 0.05 & LT & $0.56^{*}$ & LT & $0.55^{*}$ \\
\hline & $1 \mathrm{~m}$ & 0.15 & $1 \mathrm{~m}$ & $0.91^{*}$ & $1 \mathrm{~m}$ & $0.59^{*}$ \\
\hline & $3 \mathrm{~m}$ & $0.63^{*}$ & & & $3 \mathrm{~m}$ & 0.2 \\
\hline & $5 \mathrm{~m}$ & $0.43^{*}$ & & & & \\
\hline & $10 \mathrm{~m}$ & $0.55^{*}$ & & & & \\
\hline \multirow[t]{5}{*}{ Punta Carrera } & HT & $0.67^{*}$ & HT & $0.90^{\circ}$ & & \\
\hline & MT & $0.77^{*}$ & MT & $0.56^{*}$ & & \\
\hline & LT & $0.36^{\circ}$ & LT & $0.33^{*}$ & & \\
\hline & $1 \mathrm{~m}$ & $0.62^{*}$ & $1 \mathrm{~m}$ & 0.08 & & \\
\hline & $3 \mathrm{~m}$ & $0.51^{*}$ & & & & \\
\hline \multirow[t]{4}{*}{ Punta Arbol } & HT & $0.62^{*}$ & & & & \\
\hline & MT & $0.21^{*}$ & & & & \\
\hline & LT & $0.33^{*}$ & & & & \\
\hline & $1 \mathrm{~m}$ & $0.77^{*}$ & & & & \\
\hline
\end{tabular}

skottsbergii and Lessonia flavicans were more abundant at Puerto del Hambre.

Significant differences in sessile community structure were found between sites along depths in Antarctic sites (Table 2). Observed differences at $1 \mathrm{~m}$ across sites were caused by differences in abundance of encrusting corallines and red turf algae, which accounted more than $62 \%$ of dissimilarities between sites. Dissimilarities at $5 \mathrm{~m}$ and $10 \mathrm{~m}$ are explained by the higher abundance of the bryozoan Inversiula nutrix Julien, 1888 and the brown algae Desmarestia sp. at Nebles Point ${ }^{3}$. These species together contributed $\sim 55 \%$ of the differences at 5 and 10 $\mathrm{m}$. All comparisons showed high dissimilarities between sites with $40 \%$ + dissimilarity of community composition ${ }^{3}$.

No differences were shown in the composition of mobile assemblages between sites across intertidal levels in the Magellan Strait (ANOSIM R $>0.1 P=0.1$ ), however, significant differences were found between sites across most subtidal depths (ANOSIM Global $R: 1 \mathrm{~m}=0.54,3 \mathrm{~m}$ $=0.49,10 \mathrm{~m}=0.48 ; 5 \mathrm{~m} \geq 0.1 P=0.1$; Table 3). Differences in the shallows were mainly due to the higher abundance of Pseudechinus magellanicus at Puerto del Hambre and Punta Arbol compared with the other sites ${ }^{3}$. At $10 \mathrm{~m}$, the

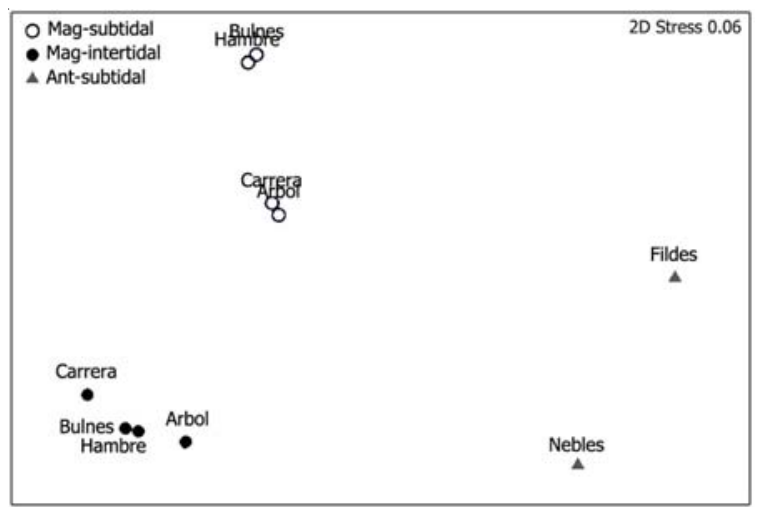

Figure 6. Non-metric multidimensional scaling (nMDS) ordination of sessile assemblages (including macroalgae) across regions (symbols) and sites (labels). Plot is based on a Bray-Curtis similarity matrix. Centroids represent site averages / Escalamiento multidimensional no-métrico (nMDS) de ensambles sésiles (incluyendo macroalgas) entre regiones (símbolos) y sitios (rótulo). El gráfico está basado en un matriz de similitud de Bray-Curtis. Centroides representan valores promedios por sitio

Table 2. $R$ values for comparisons between sessile and mobile assemblages at different sites studied in Antarctica. (* $^{*}$ significant differences) / Valores $\mathrm{R}$ para las comparaciones entre ensambles sésiles y móviles de diferentes sitios estudiados en Antártica $\left(^{*}=\right.$ diferencias significativas)

\begin{tabular}{lrc}
\hline & Nebles & Point \\
\hline Sessile & & \\
$\quad$ Fildes Bay & $1 \mathrm{~m}$ & $0.35^{*}$ \\
& $5 \mathrm{~m}$ & $0.50^{*}$ \\
& $10 \mathrm{~m}$ & $1.00^{*}$ \\
Mobile & & \\
$\quad$ Fildes Bay & $1 \mathrm{~m}$ & 0.22 \\
& $5 \mathrm{~m}$ & $0.42^{*}$ \\
& $10 \mathrm{~m}$ & $0.49^{*}$ \\
\hline
\end{tabular}

sea urchins P. magellanicus and Arbacia dufresnii (Blainville, 1825) constituted the majority of between-site differences as $P$. magellanicus was more abundant at Puerto del Hambre while A. dufresnii dominated at Fuerte Bulnes. At Antarctic sites, differences increased with depth (Table 2). Differences were produced mainly by changes in abundance of $N$. concinna between sites in the shallows, and echinoderms at 5 and $10 \mathrm{~m} \mathrm{depth}^{3}$. 
Table 3. $\mathbf{R}$ values of pairwise tests for comparisons between mobile assemblages at different sites studied in the Magellan Strait $(*=$ significant differences) / Valores $\mathrm{R}$ de las pruebas de comparación pareadas entre ensambles móviles de diferentes sitios estudiados en el Estrecho de Magallanes ( ${ }^{*}=$ diferencias significativas)

\begin{tabular}{lrlllll}
\hline & Puerto del Hambre & Punta Arbol & \multicolumn{2}{c}{ Punta Carrera } \\
\hline Fuerte Bulnes & $1 \mathrm{~m}$ & $0.34^{*}$ & $1 \mathrm{~m}$ & $0.55^{*}$ & $1 \mathrm{~m}$ & $0.87^{*}$ \\
& $3 \mathrm{~m}$ & 0.05 & & & $3 \mathrm{~m}$ & $0.73^{*}$ \\
& $10 \mathrm{~m}$ & $0.48^{*}$ & & & & \\
Punta Carrera & $1 \mathrm{~m}$ & $0.86^{*}$ & $1 \mathrm{~m}$ & $0.75^{*}$ & & \\
& $3 \mathrm{~m}$ & $0.63^{*}$ & & & & \\
Punta Arbol & $1 \mathrm{~m}$ & 0.18 & & & & \\
\hline
\end{tabular}

\section{Discussion}

Subtidal reef communities have been described in most temperate and boreal regions (Schiel \& Hickford 2001), but data from the world's most extensive subantarctic coastline is scarce. Here we presented benthic assemblage data (organisms $>2 \mathrm{~cm}^{2}$ ) from easily accessible sites in Magallanes and the South Shetland Islands.

Despite substantial M. pyrifera forests at each site, and a similar aspect and exposure across sites, subtidal sessile benthic assemblages within Magallanes varied as much as in Antarctic sites. High heterogeneity in fauna directly associated with Macrocystis in Magallanes has been found by other researchers (Adami \& Gordillo 1999, Ríos et al. 2007) and Benedetti-Cecchi and Cinelli (1997) found high between-site heterogeneity in intertidal assemblages along the Magellan Strait. At our sites in Magallanes, however, there was high similarity in community composition within each of two pairs of sites with similar physical characteristics. Fuerte Bulnes and Puerto del Hambre are close to each other, and both have reef extending to over $20 \mathrm{~m}$ depth. Punta Arbol and Punta Carrera are located either side of the Bulnes-Hambre site pair, and at both sites reef gives way to sand at $<5 \mathrm{~m}$ depth. Landscape factors could drive differences in community structure any number of ways, from hydrodynamics or ecosystem boundaries mediating food or nutrient supplies, to scouring by adjacent sands, through to predator refuge or access.

Subtidal community composition was very different at our two Antarctic sites. The dominant macroalgae was
Himantothallus grandifolius at Fildes Bay, and Desmarestia spp. at Nebles Point. These macroalgae are often found at deeper and shallower sites respectively, a pattern ascribed to different disturbance histories (Dayton 1990, Klöser et al. 1996, Clark et al. 2011). Our sites differed in many factors which may drive differences in community structure, and limited spatial replication disallowed any analysis of causal factors in between-site differences. Factors such as type and inclination of the substrate, ice impact and water turbulence may result in the dominance of Desmarestia or Himantothallus over the other (Klöser et al. 1996). The sites have similar relief, but Nebles Point was closer to the Collins Glacier, and communities may therefore be expected to show the effects of more severe ice damage (Klöser et al. 1996, Dayton 1990, Gutt 2001). Desmarestia dominance may indicate higher disturbance (Dayton 1990, Clark et al. 2011), however many of these plants appeared well established, and had thick stipes and large complex holdfasts. While Clark et al. (2011) also suggested that the higher sponge abundance and diversity under Himantothallus may indicate a more stable community; we found a higher abundance and diversity of sponges under Desmarestia. Moreover, at depth $(10 \mathrm{~m})$ the substrate at Fildes Bay site was more broken up than the solid bedrock found at Nebles Point. Again this may be causal of variation in benthic assemblages (Klöser et al. 1996, Smale 2008) but is in conflict with the theory that Himantothallus is associated with more stable environments. 
Many described shallow benthic communities from the Antarctic Peninsula have been dominated by encrusting organisms (Barnes 1995, Bowden 2005, Smale 2008) rather than seaweed-dominated, although robust and diverse macroalgal communities are known (Quartino \& Boraso de Zaixso 2008). The sites we describe have substantial seaweed cover from only $5 \mathrm{~m}$ depth. The dominance of large perennial subtidal seaweeds that form dense cover is a key element of community structure that is shared between these Antarctic and the Magellan Strait rocky reef communities. Large macroalgae can play a fundamental role in the distribution patterns and diversity of other organisms modifying physical factors such as light or water movement (Reed \& Foster 1984, Bulleri et al. 2002). The abundance of large macroalgae is likely an important aspect of the production and fate of primary productivity within these benthic systems. Macroalgae can be substantial contributors to local primary productivity in the South Shetland Islands, and can reach biomasses of greater than $10 \mathrm{~kg} \mathrm{~m}^{-2}$ wet weight (Quartino \& Boraso de Zaixso 2008). Furthermore secondary productivity will be strongly affected by seaweeddwelling crustacea (Taylor 1998) which can reach densities of at least 3750 and $10,600 \mathrm{~kg}$ (wet weight) seaweed ${ }^{-1}$ in the Magellan Strait and Fildes Bay respectively, and constitute a biomass of at least 4.6 and $5.4 \mathrm{~g}$ AFDW kg (wet weight) seaweed ${ }^{-1}$ (Newcombe, unpubl. data).

Our findings (across rocky substrate) do not support the pattern of higher species richness with increasing depth (and changing substrate) found by Ríos (2007) for benthic communities in Magallanes. At our Antarctic sites we found increasing species richness with increasing depth, consistent with past findings from Antarctica, an effect generally attributed to the decrease in ice damage with depth (Barnes 1995, Smale 2008).

Ice is a major force structuring Antarctic benthic communities (Barnes 1995, Gutt 2001, Smale 2008) but at our sites there was little evidence of recent ice damage below $5 \mathrm{~m}$ depth (it is likely that prevailing winds or storms cause greater iceberg damage on the west-facing coasts). In the shallows ( $<5 \mathrm{~m}$ to intertidal), sessile growth is limited largely to relatively fast-growing algal taxa, whereas at $10 \mathrm{~m}$, sessile invertebrate such as bryozoans, encrusting and massive sponges are more abundant. In the Magellan Strait the surface canopy of Macrocystis pyrifera apparently limits the growth of understory algae, most likely due to shading (Reed \& Foster 1984, Graham et al. 2007). Ice damage in Antarctica, and shading by
Macrocystis in Magellan Strait are likely strong structuring factors in their respective communities, which would need to be considered when comparing community characteristics with increasing depth.

Variation in structure and species dominance means that care needs to be exercised in site selection for future studies. Further detailing of sites by other researchers would build up a substantial base for development of future studies in what could be a useful site in latitudinal studies, or as a comparative system to northern hemisphere sites. Accessible sites in Magallanes and the South Shetland Islands present prime opportunities to extend ecological studies of seaweed forests to southern latitudes. The provision of basic benthic assemblage and community structure descriptive data is an important precursor to the development of more ecological studies in these areas. Key ecological questions to be addressed in these systems include the causes of Desmarestia or Himantothallus dominance on Antarctic reefs, and the role of landscape in driving structural differences in Magallanes. Annual cycles of productivity in Magallanes may be informative in comparison with Antarctic seasonal dynamics.

\section{ACKNOWLedgMenTs}

The authors would like to thank the following taxonomists: Dr. Juan López Gappa, Museo Argentino de Ciencias Naturales 'Bernardino Rivadavia', Buenos Aires, Argentina (Bryozoa); Dr. Eduardo Hajdu, Museu Nacional, Universidade Federal do Rio de Janeiro, Brasil (Porifera); Dr. Marcos Tatián, Universidad Nacional de Córdoba, Argentina (Ascidiacea); Dr. María Eugenia Manjón-Cabeza, Universidad de Málaga, Spain (Asteroidea); MSc(c). Mauricio Palacios, Universidad de Magallanes, Chile (macroalgae). We are grateful to Carlos Olavarría for his suggestions at different stages of the project and review of the manuscript. This study was funded by projects FIC-R 2008 'Biodiversidad Marina Costera en Magallanes' and INACH T12-08 'Estructura de comunidades bentónicas en arrecifes rocosos Antárticos'. The Wanaka Terraces Trust provided funds for purchase of a compressor.

\section{LITERATURE CITED}

Adami ML \& S Gordillo. 1999. Structure and dynamics of the biota associated with Macrocystis pyrifera (Phaeophyta) from the Beagle Channel, Tierra del Fuego. Scientia Marina 63: 183-191. 
Arntz W. 2005. The Magellan-Antarctic connection: links and frontiers at southern latitudes. Summary review. Scientia Marina 69(2): 359-365.

Barnes DKA. 1995. Sublittoral epifaunal communities at Signy Island, Antarctica. II. Below the ice-foot zone. Marine Biology 121: 565-572.

Benedetti-Cecchi L \& F Cinelli. 1997. Spatial distribution of algae and invertebrates in the rocky intertidal zone of the Strait of Magellan: are patterns general? Polar Biology 18: 337-343.

Bowden D. 2005. Quantitative characterization of shallow marine benthic assemblages at Ryder Bay, Adelaide Island, Antarctica. Marine Biology 146: 1432-1793.

Bulleri F, L Benedetti-Cecchi, S Acunto, F Cinelli \& S Hawkins. 2002. The influence of canopy algae on vertical patterns of distribution of low-shore assemblages on rocky coasts in the northwest Mediterranean. Journal of Experimental Marine Biology and Ecology: 89-106.

Castilla J \& CA Moreno. 1982. Sea urchins and Macrocystis pyrifera: Experimental test of their ecological relations in southern Chile. In: Lawrence JM (ed). International Echinoderms Conference, Tampa Bay, pp. 257-263. A. A. Balkema, Rotterdam.

Castilla J \& N Rozbaczylo. 1985. Rocky intertidal assemblages and predation on the gastropod Nacella (Patinigera) concinna at Robert Island, South Shetland Antarctica. INACH Serie Científica 32: 65-73.

Clark G, J Stark, L Perrett, N Hill \& E Johnston. 2011. Algal canopy as a proxy for the disturbance history of understorey communities in East Antarctica. Polar Biology 34: 781-790.

Clarke K \& R Gorley. 2006. Primer v6: User manual/tutorial, 190 pp. Primer E- Ltd., Plymouth.

Dayton P. 1985a. Ecology of kelp communities. Annual Review of Ecology and Systematics 16: 215-245.

Dayton P. 1985b. The structure and regulation of some South American kelp communities. Ecological Monographs 55: 447-468.

Dayton PK. 1990. Polar benthos. In: Smith W (ed). Polar oceanography, Part B: Chemistry, biology, and geology, pp. 631-685. Academic Press, London.

Escribano R, M Fernández \& A Aranís. 2003. Physicalchemical processes and patterns of diversity of the Chilean eastern boundary pelagic and benthic marine ecosystems: An overview. Gayana Zoología 67: 190-205.

Försterra G, L Beuck, V Häussermann \& A Freiwald. 2005. Shallow water Desmophyllum dianthus (Scleractinia) from Chile: characteristics of the biocenoses, the bioeroding community, heterotrophic interactions and (palaeo)bathymetrical implications. In: Freiwald A \& J Roberts (eds). Cold-water corals and ecosystems, pp. 937-977. Springer-Verlag, Berlin, Heidelberg.
Graham MH, J Vásquez \& A Buschmann. 2007. Global ecology of the giant kelp Macrocystis: from ecotypes to ecosystems. Oceanography \& Marine Biology: An Annual Review 45: 39-88.

Gruzov EN \& AF Pushkin. 1970. Bottom communities of the upper sublittoral of Enderby Island and the South Shetland Islands. In: Holdgate M (ed). Antarctic ecology, pp. 235238. Academic Press, London.

Gutt J. 2001. On the direct impact of ice on marine benthic communities, a review. Polar Biology 24: 553-564.

Guzmán L \& C Ríos. 1986. Análisis de la estructura en comunidades intermareales archipiélago de Cabo de Hornos: ambientes de bloques y cantos. Estudios Oceanológicos 5: 67-105.

Häussermann V \& G Försterra. 2007. Extraordinary abundance of hydrocorals (Cnidaria, Hydrozoa, Stylasteridae) in shallow water of the Patagonian fjord region. Polar Biology 30: 487-492.

Iken K \& B Konar. 2003. Natural Geography in Nearshore Areas (NaGISA): The nearshore component of the Census of Marine Life. Gayana 67: 153-160.

Ingólfsson A. 2005. Community structure and zonation pattern of rocky shores at high latitudes: an interocean comparison. Journal of Biogeography 32: 169-182.

Kim D. 2001. Seasonality of marine algae and grazers of an Antarctic rocky intertidal, with emphasis on the role of the limpet Nacella concinna Strebel (Gastropoda: Patellidae). Berichte zur Polar und Meeresforschung 397: 1-136.

Klöser H, M Quartino \& C Wiencke. 1996. Distribution of macroalgae and macroalgal communities in gradients of physical conditions in Potter Cove, King George Island, Antarctica. Hydrobiologia 333: 1-17.

Moyano H. 1996. Holocene bryozoan links between Australia, New Zealand, southern South America, and Antarctica - a preliminary evaluation. In: Gordon D, A Smith \& J GrantMackie (eds). Bryozoa in space and time, pp. 207-219. NIWA, Wellington.

Ojeda FP \& B Santelices. 1984. Invertebrate communities in holdfasts of the kelp Macrocystis pyrifera from southern Chile. Marine Ecology Progress Series 16: 65-74.

Quartino M \& A Boraso de Zaixso. 2008. Summer macroalgal biomass in Potter Cove, South Shetland Islands, Antarctica: its production and flux to the ecosystem. Polar Biology 31: 281-294.

Reed DC \& MS Foster. 1984. The effects of canopy shading on algal recruitment and growth in a giant kelp forest. Ecology 65: 937-948.

Rigby P, K Iken \& Y Shirayama. 2007. Sampling diversity in coastal communities. NaGISA protocols for seagrass and macroalgal habitats, 145 pp. Kyoto University Press, Kyoto. 
Ríos C. 2007. Marine benthic communities of the Magellan Region, southern Chile: contributions of different habitats to the overall diversity. Doktors der Naturwissenschaften, Universität Bremen, Bremen, 122 pp.

Ríos C \& E Mutschke. 1999. Community structure of intertidal boulder-cobble fields in the Straits of Magellan, Chile. Scientia Marina 63: 193-201.

Ríos C, W Arntz, D Gerdes, E Mutschke \& A Montiel. 2007. Spatial and temporal variability of the benthic assemblages associated to the holdfasts of the kelp Macrocystis pyrifera in the Straits of Magellan, Chile. Polar Biology 31: 89-100.

Sakurai H, T Sato, H Arai, A Takasaki, S Tada, H Hori, I Kimpara, T Matsuyama \& M Kodama. 1996. Habitats of fish and epibenthic invertebrates in Fildes Bay, King George Island, Antarctica. Proceedings of the NIPR Symposium on Polar Biology 9: 231-242.

Schiel DS. 1990. Macroalgal assemblages in New Zealand: Structure, interactions and demography. Hydrobiologia 192: 59-76.

Schiel DR \& MJH Hickford. 2001. Biological structure of nearshore rocky subtidal habitats in southern New Zealand. Science for Conservation 182: 1-54.

Smale D. 2008. Continuous benthic community change along a depth gradient in Antarctic shallows: evidence of patchiness but not zonation. Polar Biology 31: 189-198.
Steneck RS, MH Graham, BJ Bourque, D Corbett, JM Erlandson, JA Estes \& MJ Tegner. 2002. Kelp forest ecosystems: Biodiversity, stability, resilience and future. Environmental Conservation 29: 436-459.

Taylor RB. 1998. Density, biomass and productivity of animals in four subtidal rocky reef habitats: The importance of small mobile invertebrates. Marine Ecology Progress Series 172: $37-51$

Thatje S \& A Brown. 2009. The macrobenthic ecology of the Straits of Magellan and the Beagle Channel. Anales del Instituto de la Patagonia 37: 17-27.

Thatje S \& E Mutschke. 1999. Distribution of abundance, biomass, production and productivity of macrozoobenthos in the sub-Antarctic Magellan Province (South America). Polar Biology 22: 31-37.

Vásquez J \& J Castilla. 1984. Some aspects of the biology and trophic range of Cosmasterias lurida (Asteroidea, Asteriinae) in belts of Macrocystis pyrifera at Puerto Toro, Chile. Medio Ambiente 7: 47-51.

Vásquez JA, JC Castilla \& B Santelices. 1984. Distributional patterns and diets of four species of seaurchins in giant kelp forest Macrocystis pyrifera of PuertoToro Navarino Island Chile. Marine Ecology Progress Series 19: 55-64. 